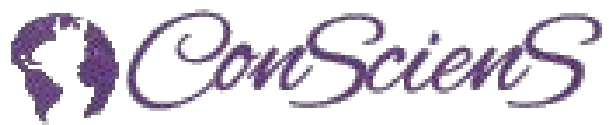

DOI: $10.5281 /$ zenodo.4058755

\title{
Economic Growth in Times of Pandemics
}

\author{
Julia M. Puaschunder ${ }^{1,2}$ \\ ${ }^{1}$ The New School, Parsons School of Design, Department of Economics, 6 East $16^{\text {th }}$ Street, $9^{\text {rd }}$ floor 89, New \\ York, NY 10003, USA, Julia.Puaschunder@newschool.edu, T 001212229 5700, F 0012122295724, \\ www.juliampuaschunder.com \\ ${ }^{2}$ Columbia University, Graduate School of Arts and Sciences, Julia.Puaschunder@columbia.edu, \\ http://blogs.cuit.columbia.edu/jmp2265
}

\begin{abstract}
Traditional economic growth theories considered capital and labor as essential growth factors for every economy. Exogenous growth theory is centered on exogenous shocks like new technology innovations or natural crises, such as pandemics - as major drivers or downturns of economic growth measured in capital and labor impact. Endogenous growth theory then drew attention to dynamic variable interactions between capital and labor but also endogenous growth derived from ideas, innovation and learning. Growth concepts were opened up for innovation generated in productive group interaction and learning inside firms in teams, learning-by-doing while performing tasks and learning-by-using of new technology. The outbreak of the novel Coronavirus (COVID-19) heightened attention for hygiene and healthcare. According to exogenous growth theory, the health risk exposure to the exogenous shock of COVID-19 differs between employees, firms, industries, environments and countries. Health of labor capital but also a risk-free working culture, environment, industry and country will flourish growth in a COVID-19-struck economy. In endogenous growth theory terms, team hygiene and group monitoring of the collective health status but also learning-to-preventing holds future economic growth potential. Applications of the presented COVID-19 adjusted growth models will be discussed with attention to inequality of growth in the digital age. Future research directions are envisioned.
\end{abstract}

KEYWORDS: Coronavirus, COVID-19, Endogenous growth, External shock, Healthcare, Hygiene, Inequality, Learning-by-preventing, Pandemic

\section{COVID-19}

The new Coronavirus (COVID-19) is an infectious disease that was first diagnosed in Wuhan, China, in December 2019. The majority of infected only develops mild symptoms such as fever, cough, difficulty breathing and tiredness as well as loss of smell and taste, but also rashes and other diffuse symptoms (Center for Disease Control and Prevention 2020). Depending on age and prevalence, COVID-19 can lead to acute complications such as organ failure, cytokine loads, blood clots and septic shock (Center for Disease Control and Prevention 2020). Pre-existing conditions, such as obesity and diabetes, but also the general status of the immune system, are crucial determinants whether the new Coronavirus is of severe danger to the individual (Salzburg Declaration 2020). Prevention and holistic medicine play an important role whether the disease turns out to follow a mild or severe symptom trajectory (EcoWellness Group 2020).

In January 2020, the World Health Organization declared a state of emergency with international relevance over COVID-19, and in March 2020 the outbreak of a global pandemic. As of August 2020, almost 24 million infected cases are documented and almost one million deaths have been recorded in over 200 countries in all six World Health Organization territories (Sachs, Horton, Bagenal, Amor, Caman \& Lafortun 2020). Exponentially growing numbers of infections and a lack of an effectively-tested vaccine or completely-curing medication so far project that there may not be a fast end to the crisis in the near future (United Nations 2020). 


\section{Economic growth}

\section{Exogenous growth theory}

Classical political economy in the tradition of Adam Smith and David Ricardo prepared ideas about the growth of capitalist economies, even if it is not in the language of modern growth theory. Standard neoclassical economic growth is captured in growth theories (Deaton 2010; Kuznets 1973). The history of standard growth theories features aggregate production function calculus as the extension of the micro-economic production function at a national or economy-wide level (Puaschunder 2020). The aggregate production function describes the relationship of the size of an economy's labor force and its capital stock with the level of the country's Gross National Product (GNP).

Growth theory had originally been focused on exogenous growth foremost pioneered in the work of Robert Solow's Growth Model (1956). Solow's neoclassical growth theory was based on the two factors capital $(K)$ and labor $(L)$, which are argued to drive every economy (Solow 1956). The value of output or national product is thereby derived from the value of the aggregate capital stock and labor force (Jones 2014). Aggregate production is explained by how capital and labor of an economy contribute to growth (Jones 1999). Economic output $(Y)$ is a function $(f)$ of capital $(K)$ and labor $(L)$ so that
$Y=f(K, L)$
(Equation 1)

Capital stock is usually improved through new investments and decreased by depreciation. Labor supply is determined by the change in labor force, for instance through population growth or education. Derivations include technology into the model insofar as output per effective worker becomes a function of capital per effective worker, whereby international differences are prevalent (Bartelsman, Haltiwanger \& Scarpetta 2013; Comin \& Hobijn 2004, 2010).

In a single commodity economy Solow (1957) assumes investment $I$ identical to savings $S(I \equiv S)$. In $S=s Y$, where $S$ is total savings, $s$ is the savings rate st $0<s<1$, and $Y$ is total output. No capital depreciation occurs as the rate of change of capital $\dot{K}=I=s Y$. Labor force $L$ grows at constant rate, $\widehat{L}=\frac{\dot{L}}{L}=n$. The technical possibilities of the economy are represented by a continuous, constant return to scale aggregate production function $Y=f(K, L)$ (Equation 2) whose intensive form is $y=f(k)$ where $y=Y / L$ and $k=K / L$. Marginal product of capital is positive for all levels of the capital labor ratio: $f^{\prime}(k)>0$ for all $k$ and diminishes as capital per worker increases: $f^{\prime \prime}(k)<0$ for all $k$. Solow's behavioral growth model and optimizing growth model assumes savings rates to be exogenously given, with propensity to consume fixed, as in Keynesian Macroeconomics $k=\frac{K}{L}, y=\frac{Y}{L}$ per capita. As $k=\frac{K}{L}$, the growth rate of $k$ is

$$
\dot{k}=s f(k)-n k \quad \text { (Equation 3) }
$$

On a Cartesian plane, the intersection of the $s f(k)$ and $n k$ lines gives the steady state of the economy. In neoclassical growth theory a balanced growth steady state solution for the model exists. This balanced rate of growth in the model is constant and equal to the exogenous labor force growth rate $n$; hence in the long run, the growth rate is independent of the savings rate. In the neoclassical tradition, though, there is no room for a lack of effective demand and under-consumption. Growth on the long run comes from exogenous shocks of which technology revolutions are of positive accelerator and multiplier nature, whereas negative shocks - such as pandemics - are negative downturns to growth.

\section{Endogenous growth theory}

Modern growth theory of $20^{\text {th }}$ century is based on the work of Harrod and Domar, Solow and Swan, and Paul Romer. Harrod and Domar started by pointing out dynamic rather than static 
growth factors during the Keynesian heterodox economics revolution. In a marriage of the acceleration principle and the multiplier theory, Harrod argued endogenous growth factors in capital and labor as accelerators that coined the term of endogenous growth theories.

In response to neoclassical growth theory missing the 'black box' of innovation in economic growth considerations, a group of economists including Paul Romer (1990), Robert Lucas (1988), Philippe Aghion and Peter Howitt (1992) sought to extend neoclassical models to incorporate endogenous innovation, hence "endogenous" growth theory in the 1990s.

New Growth Theory starts with Romer (1986), where persistent growth was explained by the impact of externalities on economic development. The idea was originally formalized by Arrow (1962) who argued that externalities arising from learning by doing and knowledge spillover positively affect labor productivity on the aggregate level of the economy.

Since the 1980s, endogenous growth theory integrated a rich set of ideas of endogenous growth of capital and labor into development economics based on ideas, learning and research and development as drivers of innovation (Bils \& Klenow 2002; Lucas 1988, 1999). Growth is determined by the production of knowledge and ideas. Innovation as in Schumpeter's creative destruction are later mathematically formalized as in the empirical models of Robert Solow (1956), Robert Lucas (1988), Philippe Aghion and Peter Howitt (1992).

Endogenous growth theory can be understood as the addition of human capital as a separate form of capital to Solow's (1956) growth model. This appears as the addition of human capital $(H)$ to the statement: Output $(Y)$ is a function $(f)$ of capital $(K)$, labor $(L)$, and innovation $(A)$ so that

$Y=A f(K, H, L)$

(Equation 4)

Lucas (1988) whose model goes back to Uzawa (1965) emphasized human capital creation as a source of growth. Romer (1990) and Grossmann and Helpman (1991) considered the creation of new knowledge as a source of growth. In Aghion and Howitt $(1992,1998)$ the Schumpeterian process of creative destruction becomes central to growth. There have been a number of empirical studies using new growth theory, with the early phase of empirical work being largely focused on cross-section studies.

In 2018 Paul Romer jointly won the Nobel Prize for economics with William Nordhaus for his contribution to integrating technological innovation with economic growth. Romer's analysis stresses innovations as non-rivalrous that involve a fixed cost of production and zero marginal cost to reproduce. As the long run rate of economic growth depends on the rate at which innovation and knowledge grow, the public sector has a vital role to play in supplementing the private provision of research and education to correct this market failure. Differences in social infrastructure play an important role in explaining differences output per worker between countries (Dinopoulos \& Thompson 1999; Hall \& Jones 1999; Klenow \& Rodriguez 1998).

The decisive difference between neoclassical growth theory and endogenous growth theory is that the latter allows for the possibility of increasing returns, whereby if all inputs are doubled, output may more than double because knowledge is non-rivalrous and not completely excludable but has an exponential growing marginal utility. The more information one holds, the more complex conclusions may be drawn. So that a doubling in the stock of knowledge can result in more than doubling of its productive utilizations by firms. In terms of economic productivity, effects come to play like learning-by-doing or in the use of complex technology learning-by-using (Puaschunder, Gelter \& Sharma forthcoming). Team learning and team management become economic growth accelerators that are attributed to be key hallmarks of the American economic growth miracle during the Cold War period (Brenner forthcoming $a, b)$. 


\section{Growth in the age of COVID-19}

\section{Exogenous shock}

In the exogenous growth theory understanding, the COVID-19 pandemic is an external shock that diminishes economic growth potential in the domains of capital and labor gains. Already now, the novel Coronavirus caused a dramatic downturn for general mobility and international tourism including gastronomy (Gössling, Scott \& Hall 2020; Puaschunder et al. 2020). In April 2020, more than half the world's population resided in countries enforcing lockdowns, which disrupted individual lives, business activities and international mobility (IMF 2020). All major world economies suppressing human social interaction, which spilled over into an economic decline around the globe comparable to the onset of the Great Depression (Sachs et al. 2020; UNDP 2020). In the wake of "social distancing" measures, consumption decreased by $32 \%$ in China, $49 \%$ in Germany and $50 \%$ in the US as well as $78 \%$ in Great Britain (Jones, Palumbo \& Brown 2020). The Financial Times Stock Exchange Group, Dow Jones Industrial Average and Nikkei plummeted in the first quarter of 2020 drastically (Jones et al. 2020). Unemployment and furloughs rose in all major market economies (Jones et al. 2020). The IMF (2020) estimates a 5-15\% chance of a recession after the first quarter of 2020 measured by Gross National Product (Sachs et al. 2020). The world economy shrunk by $3 \%$ in the first quarter and is expected to decline around $5 \%$ throughout 2020 (IMF 2020). The 2021 global growth is projected at 5.4\%, which leaves the 2021 GDP some 6.5 percentage points lower than in the pre-COVID-19 projections of January 2020. All these measures resemble the onset of the Great Depression of the 1930s, which - together with subsequent events - changed the corporate governance structure and conduct dramatically, unprecedentedly and lastingly (Sachs, 2020; Gelter \& Puaschunder work in progress).

\section{Endogenous growth}

Despite the enormous economic growth decline already obvious and prospected in the years to come, there is endogenous growth potential in the wake of COVID-19 that includes attention to natural health selection, hygiene and collective healthcare.

In the novel Coronavirus crisis, prevention and general, holistic medicine determine whether COVID-19 puts patients on a severe or just mild symptom trajectory. Obesity, but also the general status of the immune system are decisive in whether the Coronavirus becomes a danger for the individual (Salzburg Declaration 2020).

In light of the heightened health risks of COVID-19, employers will naturally select healthier workers that may have a positive externality effect of an overall more productive labor at work. Already now elder and chronic patients' passing and vulnerabilities risks change labor market demand towards favoring young, healthier and Corona-survivors, who may benefit from a natural immunity, and being more virus-resistant (Schwartz Center for Economic Policy Analysis Older Worker's Report 2020). Needless to say, the expected economic growth potential should also be considered to be taxed and the extra fiscal space used to offset the socio-economic losses and social misery implied in inequalities in market selection.

As for outside working conditions, those corporations that are placed in benevolent health-promoting territories will have a competitive advantage and gain in terms of labor quality. Countries around the world are currently paying attention to preventive medical care in the wake of pandemic outbreak monitoring. Those nations that can offer technological advancements to monitor pandemic outbreaks but also medicine of the future that helps prevent diseases instead of just treating their consequences will produce positive labor advantages (Puaschunder \& Beerbaum 2020; Puaschunder, Mantl \& Plank 2020; Puaschunder 2020; Salzburg Declaration 2020). 
On the corporate level, those corporations that manage to build a healthy environment that is attentive to prevention will gain from COVID-19 on the long run. Corporations that invest in hygiene but also group learning and team skills of hygienic working conduct will likely see a long-term labor-driven economic growth. In light of pre-existing conditions and obesity determining the likelihood of severity trajectory, corporations may also focus on fostering a healthy and ecological diet of their employees. Measures that can guarantee continued health in employment will account for corporate success and economic growth.

Corporate governance could therefore foster self-monitoring of the state of health of employee and the comprehensive prevention in a holistic lifestyle. For instance, the German Prevention Act of 2015 of the German Federal Government compensates corporations for fostering investment in preventive self-care but also team learning of healthy lifestyles in the workforce, acknowledging the power of preventive care for economic productivity. Focusing on collective health as a common good will on the long run make labor components more productive. All these means of a hygienic environment, healthy preventive care and workplace interactions may be summed up in learning-by-preventing economic growth potential.

\section{Model}

Contemporary growth theory should be revised as for integrating growth related to hygiene and health as positive input but also risk factor. Growth theory should consider labor to be either flexible or inflexible (Puaschunder 2020). Flexible labor would potentially be parts of labor that can work remotely, be dismissed, exchanged or furloughed during the COVID-19 pandemic to not spread the disease and/or be affected. Other parts of labor may be more inflexible, as would be traditional human labor force that cannot work remotely and cannot be replaced. In an endogenous growth theory frame, these parts of the workforce should be cautioned and trained to be hygienic and remain healthy, hence it should be invested in their long-term health status. This innovation would comprise of learning-by-preventing activities for workgroups and team learning of monitoring one's own health and the health status of coworkers and others.

Together these micro-macro endogenous and exogenous growth theory innovations should integrate a novel component for health that should be formalized into the standard growth theory formula as proposed:

$$
Y n(t)=(A(t) K(t))^{\alpha}(A(t) L(t))^{\beta}(A(t) H(t))^{1-\alpha-\beta}
$$

whereby $Y n(t)$ denotes total new production function, $A(t)$ refers to capital and healthaugmenting technologies or health status knowledge, $K(t)$ is capital and $L(t)$ labor. $H(t)$ represents health information and training, which corporations can foster among the entire workforce and make more accessible. Information share on health status and monitoring one's own health but also the health of others on the work team are most novel innovations that may drive economic growth during COVID-19. Access to information about health and virus spreading but also reaping benefits from information sharing on other's health status through synergizing information and deriving inferences in relation to big data on virus outbreaks are innovative value generation in work teams during COVID-19. Health and knowledge about other's health status in a corporation as a collective asset and learning-bypreventing in teams is an addition to conventional capital or labor skills. Having a big data collection on the health status of the workforce enhances the productivity of $H(t)$ due to network effects and information being a non-rivalrous good, with a marginal utility gain that is exponential. Network effects from information and connectivity increase per additional user. Information is non-rivalrous as the consumption of one piece of information does not decrease or deplete the opportunity for another person to consume the information. The more 
information one holds, the better - hence the marginal utility of information rises exponentially with information gain. In all these features - network effect gains, nonrivalrous information consumption opportunities and exponential marginal utility gains of knowledge - information is completely different from classical notions of capital and labor. Where capital and labor are exclusive, the knowledge economy and big data on health status driven growth are non-exclusive (Clancy 1998). A piece of information shared or written online does not does not take anything away or decrease utility, it actually increases people's utility non-depletably and aids as risk management in following the precautionary principle in pandemic economies (Stiglitz 1998; Stroebe, \& Frey 1982). Therefore, it is proposed to measure health information as completely novel component to be considered in standard growth theory. Economically, the current Artificial Intelligence and big data insights revolution can aid in tracking, monitoring and improving individual and group health statuses (Lucas 2004; Puaschunder 2019a, b). Prevention is an additional asset of learning-bypreventing as for tapping into the economic benefits of the precautionary principle and lowering health and long-term litigation risks.

The proposed assumptions and modeling are a very preliminary introduction to economic growth gains from health and preventive care in work teams. As for the novel character, it should be theoretically clarified, empirically measured and model generation backtested on data to clarify whether and to quantify how much health and preventive care in teams enhances labor components of standard growth theories.

\section{Discussion}

Today's economies around the world are affected by the pandemic and health crisis. Yet the unprecedented attention to topics of "systemic, sustainable prevention" - just like ecological topics - can stimulate the innovative strength of the economy and generate new, lucrative business models and products that also minimize the pandemic consequences. Future innovations in the medical field are predestined to be in the realm of digitized health care and self-monitoring with the help of electronic self-measuring devices and modern molecular genetic analyzes. These can make the use of new active ingredients in the field of prevention of serious diseases more efficient. It is a sad fact that most drugs do not work satisfactorily or have side effects, with increasing costs and high risks as well as unequal distribution and access to around the world. Therefore the drive towards the precautionary principle and collective attention to hygiene and preventive medicine offer novel economic growth potential that should be integrated in standard exogenous and endogenous growth theory. With new business models, however, social implications, such as evolutionary selection mechanisms encroaching on corporate actions or ethical limits to privacy and the democratization of information should also be considered in order to be alleviated.

As an addition to the current model, digitalization may be integrated in a future extension. In today's economy, robots and algorithms are taking over human decisionmaking tasks and entering the workforce. Most recently, big data has evolved to become a source of economic growth and governments in major economies are endeavoring to tax wealth creation from information transfer. Modern healthcare today is based on mobile monitoring and relies more than ever on AI by analyzing a large amounts of data for prevention, diagnosis and healing.

Future studies may empirical validate the proposed economic growth changes with attention to AI, big data insight, robotics and algorithms entering the medical profession. This trend currently challenges conventional economic theory to capture growth based on purely capital and labor components (Puaschunder 2020). Algorithms, machine learning and big data gains but also the shared economy do not seem to be represented accurately in conventional growth theory components of capital and labor (Alvarez, Buera \& Lucas 2007). 
To this day, we do not have clear information where to integrate AI and big data insightderived economic gains into standard economic growth theory (Puaschunder 2020). It is not clarified whether these components are enhancing the production process, hence are considered as capital $K$ or aid as human-enhancement more the labor component $L$ or are even imposing a burden on economic growth for set-up costs and litigation risks (Puaschunder 2020).

Future empirical validations of the proposed ideas should be tested cross-sectionally and by time series. Cross-sectional studies could differentiate between countries, while time series would allow to control for general economic trends. However, cross-sectional studies are often comparing countries at different stages of development and imply preference and technology parameters being identical for all countries in the sample. Differences in institutional conditions and social infrastructure are also to be expected in actuality, leading to heterogeneity of estimated parameters that the models (Brock \& Durlauf 2001).

A time-series approach takes into account changes over time and stages of development, yet are challenged by eventual non-stationarity that requires transformation into a stationary model. Drawbacks include the possibility of structural breaks and high data requirements. Scale effects may occur as an increase in the level of state economic variables such as human capital or knowledge capital implying strong and lasting effects on the growth rate of the economy, which requires the introduction of nonlinearities. Time-series would require a high quality of data or curing unobservable variables' missing data to be replaced by observable lower-quality ones. Including non-linearities into the empirical model helps avoid scale effects which seem implausible due to diminish forces of growth.

\section{References}

Aghion, Philippe \& Peter Howitt. 1992. "A model of growth: Through creative destruction.” Econometrica 60 (2): 323-351.

Aghion, Philippe \& Peter Howitt. 1998. Endogenous growth theory. Cambridge, MA: MIT Press.

Alvarez, Fernando, Francisco Buera \& Robert E. Lucas. 2007. Idea flows, economic growth, and trade, 2007. National Bureau of Economic Research working paper retrieved at https://www.nber.org/papers/w19667.

Bartelsman, Eric J., John Haltiwanger \& Stefano Scarpetta. 2013. Cross-country differences in productivity: The role of allocation and selection. American Economic Review 1(103): 305-334.

Bils, Mark \& Peter J. Klenow. 2002. "Does schooling cause growth?” American Economic Review 90(5): 11601183.

Brenner, Robert. forthcoming a. "The puzzle of the long downturn." In R. Brenner, The Economics of Global Turbulence: The Advanced Capitalist Economies from Long Boom to Long Downturn, 1945-2005. New York: Verso.

Brenner, Robert. forthcoming b. "From boom to downturn." In R. Brenner, The Economics of Global Turbulence: The Advanced Capitalist Economies from Long Boom to Long Downturn, 1945-2005. New York: Verso.

Brock, William A. \& Steven N. Durlauf. 2001. Discrete choice with social interactions. Review of Economic Studies 68: 235-260

CDC Center for Disease Control and Prevention, 2020. Symptoms of Coronavirus Disease, Coronavirus Disease 2019 (COVID-19), https:/www.cdc.gov/coronavirus/2019-ncov/symptoms-testing/symptoms.html (last visited August 12, 2020).

Clancy, Erin A. 1998. "The tragedy of the global commons." Indiana Journal of Global Legal Studies 5(2): 601619.

Comin, Diego \& Bart Hobijn. 2010. "An exploration of technology diffusion.” American Economic Review 100 (5): 2031-2059,

Comin, Diego \& Bart Hobijn. 2004. Cross-country technology adoption: Making the theories face the facts. Journal of Monetary Economics 51 (1): 39-83.

Deaton, Angus. 2010. "Understanding the mechanisms of economic development." Journal of Economic Perspectives 24(3): 3-16. 
Dinopoulos, Elias \& Peter Thompson. 1999. "Scale effects in Schumpeterian models of economic growth." Journal of Evolutionary Economics 9: 157-185.

EcoWellness Group, 2020. Interdisciplinary Conference on 'System change?! The chance of transformation of the healthcare system: Analysis and chances of the coronavirus crisis, July 14-15, 2020, https://www.oekowellness.de/laenderuebergreifende-konzerenz-zum-thema-system-change-die-chanceder-transformation-des-gesundheitswesens-14-07-2020/ (last visited August 12, 2020).

Gössling, Stefan, Daniel Scott \& C. Michael Hall. 2020. Pandemics, tourism and global change: a rapid assessment of COVID-19, forthcoming in Journal of Sustainable Tourism, 2020.

Grossman Gene M. \& Elhanan Helpman. 1991a. Innovation and growth in the global economy. Cambridge, MA: MIT Press.

Grossman Gene M. \& Elhanan Helpman. 1991b. "Quality ladders in the theory of growth.” Review of Economic Studies 58(1): 43-61.

Hall, Robert E. \& Charles Jones. 1999. "Why do some countries produce so much more output per worker than others?" The Quarterly Journal of Economics 114 (1): 83-116.

International Monetary Fund, 2020. A crisis like no other: An uncertain recovery. World Economic Outlook Update, 2020 (June 2020).

International Monetary Fund, Policy Responses to COVID-19, 2020, https://www.imf.org/en/Topics/imf-andcovid19/Policy-Responses-to-COVID-19 (last visited August 13, 2020).

Jones, Benjamin F. 2014. "The human capital stock: A generalized approach." American Economic Review 104 (11): 3752-3777.

Jones, Charles I. 1999. “Growth: With or without scale effects.” American Economic Review 89 (2): 139-144.

Jones, Lora, Daniele Palumbo \& David Brown, 2020. Coronavirus: A visual guide to the economic impact, BBC NEws, https://www.bbc.com/news/business-51706225 (June 30, 2020).

Klenow, Pete \& Andres Rodríguez-Clare. 1997. "Economic growth: A review essay." Journal of Monetary Economics 40(4): 597-618.

Kuznets, Simon. 1973. "Modern economic growth: Findings and reflections." American Economic Review 63(3): 247-258.

Lucas, Robert E. 1988. "On the mechanics of economic development.” Journal of Monetary Economics 22: 342.

Lucas, Robert E. 2004. “The industrial revolution: Past and future.” Annual Report of the Federal Reserve Bank of Minneapolis, May, pp. 5-20.

Lucas, Robert E. 1999. "Why doesn't capital flow from rich to poor countries?" American Economic Review 80 (5): 92-96.

Puaschunder, Julia Margarete \& Dirk Beerbaum. forthcoming. "Healthcare inequality in the digital $21^{\text {st }}$ century: The case for a mandate for equal access to quality medicine for all." Proceedings of the Unequal World Conference, United Nations New York, New York, United States.

Puaschunder, Julia Margarete, Josef Mantl \& Bernd Plank. 2020. "Medicine of the future: The power of Artificial Intelligence (AI) and big data in healthcare." RAIS Journal for Social Sciences 4(1): 1-8.

Puaschunder, Julia Margarete. Artificial Intelligence, big data, and algorithms in healthcare, Report on behalf of the European Parliament European Liberal Forum in cooperation with The New Austria and Liberal Forum, 2019b. Retrieved at https://papers.ssrn.com/sol3/papers.cfm?abstract_id=3472885

Puaschunder, Julia Margarete. Martin Gelter \& Siegfried Sharma. 2020. COVID-19-Shock: SocioTechnological, Legal, Corporate, Economic and Governance Changes. Proceedings of the 18th Interdisciplinary Research Association for Interdisciplinary Studies (RAIS) conference, August 17-18, 2020. [Held online due to COVID-19].

Puaschunder, Julia Margarete. 2020. "Revising growth theory in the Artificial Age: Putty and clay labor." Archives in Business Research 8(3): 65-107.

Puaschunder, Julia Margarete. forthcoming b. "The future of Artificial Intelligence in international healthcare: Integrating technology, productivity, anti-corruption and healthcare interaction around the world with three indices." Journal of Applied Research in the Digital Economy.

Puaschunder, Julia Margarete. 2019g. The legal and international situation of AI, robotics and big data with attention to healthcare. Reports on behalf of the European Parliament European Liberal Forum in cooperation with The New Austria and Liberal Forum, Retrieved at https://papers.ssrn.com/sol3/papers.cfm?abstract_id=3472885

Romer, Paul M. 1990. "Endogenous technological change.”. Journal of Political Economy 98(5): 71-102.

Romer, Paul M. 1986. Increasing returns and long-term growth. The Journal of Political Economy 94(5): 10021037.

Sachs, Jeffrey D., Richard Horton, Jessamy Bagenal, Yanis Ben Amor, Ozge Karadag Caman \& Guillaume Lafortun. 2020. The Lancet COVID-19 Commission, The Lancet (July 9, 2020), https://www.thelancet.com/pdfs/journals/lancet/PIIS0140-6736(20)31494-X.pdf, https://doi.org/10.1016/S0140-6736(20)31494-X 
Salzburg Declaration, 2020. EcoWellness Group ICQ on behalf of the World Economic Forum Reset Programme, 2020.

Schwartz Center for Economic Policy Research Older Workers Report: Over Half of Unemployed Older Workers at Risk of Involuntary Retirement, https:/www.economicpolicyresearch.org/jobs-report/overhalf-of-older-workers-unemployed-at-risk-of-involuntary-retirement (August 5, 2020).

Solow, Robert. 1956. "A contribution to the theory of economic growth." The Quarterly Journal of Economics, 70 (1): 65-94.

Stiglitz, Joseph. 1998. "The private uses of public interests: Incentives and institutions." Journal of Economic Perspectives 12: 3-22.

Stroebe, Wolfgang \& Bruno S. Frey. 1982. "Self-interest and collective action: The economics and psychology of public goods." British Journal of Social Psychology 21 (2): 121-137.

United Nations Conference on Trade and Development Committee for the Coordination of Statistical Activities, How COVID-19 is changing the world: A statistical perspective, 2020, https://unstats.un.org/unsd/ccsa/documents/covid19-report-ccsa.pdf (last visited August 13, 2020).

United Nations, UN Response to COVID-19, https://www.un.org/en/coronavirus/UN-response (last visited August 12, 2020)

Uzawa, Hirofumi. 1965. "Technical change in an aggregative model of economic growth." International Economic Review 6(1): 18-31. 